\title{
HOTSPOT: The Snake River Scientific Drilling Project- Tracking the Yellowstone Hotspot Through Space and Time
}

\author{
by John W. Shervais, Michael J. Branney, Dennis J. Geist, Barry B. Hanan, \\ Scott Hughes, Alexsander A. Prokopenko, and Douglas F. Williams
}

doi:10.2204/iodp.sd.3.14.2006

Mantle plumes play a crucial role in Earth's thermal and tectonic evolution. Plumes have long been implicated in the breakup and rifting of continents, and plume-derived melts play a significant role in the creation and modification of the sub-continental mantle lithosphere. Hotspot volcanism in the oceanic lithosphere has been the subject of intense recent study by the Hawaii Scientific Drilling Project, and studies conducted by the Integrated Ocean Drilling Program (IODP) will examine further the role of mantle plumes in oceanic settings. These drilling efforts provide baseline information about where mantle plumes originate, how they behave, and what the volcanic products of these processes are. In contrast, the impacts of hotspot volcanism on the continental lithosphere are poorly understood because active continental hotspot systems are limited to surface exposures of volcanic provinces that are too young to be exposed by erosion.

The Snake River Plain volcanic province, which begins under eastern Oregon, U.S.A. and ends at the Yellowstone plateau about $350 \mathrm{~km}$ to the east, represents a hotspot track beneath the continental crust (Fig. 1). Basalts of the Snake River Plain are compositionally similar to ocean-island basalts and preserve a record of volcanic activity that spans over $12 \mathrm{Ma}$. The Snake River province is still active today, with flows as young as 6000 years, and it represents a worldclass example of active, intra-continental, mantle-plume volcanism. In addition, the western Snake River Plain preserves an archive of late Neogene paleoclimatic evolution hosted within deep-water lacustrine sediments. The complete record of volcanic activity can only be sampled by drilling

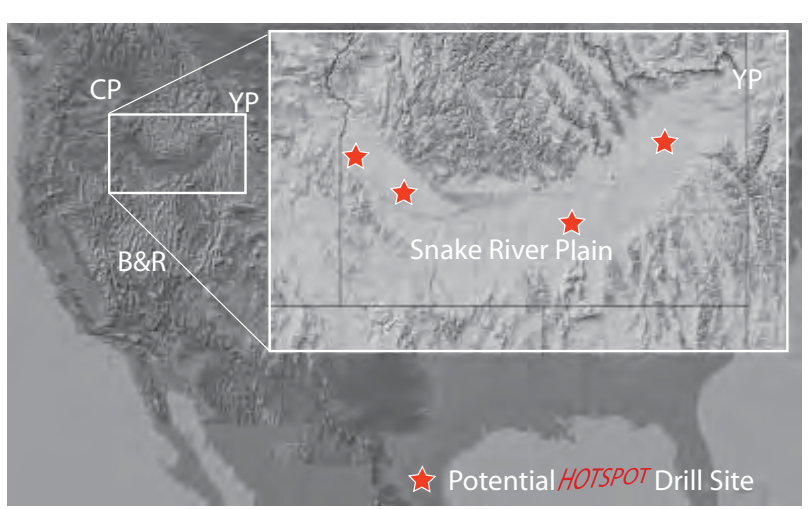

Figure 1. Digital elevation model of southern Idaho showing Snake River Plain and its relation to flood basalts of Columbia Plateau in Washington and Oregon (CP), Basin \& Range area (B\&R), and Yellowstone plateau (YP). Potential drilling sites are shown as red stars because the plain is young and tectonically undisturbed, with limited exposure of the stratigraphic sequence.

The project "HOTSPOT: Scientific Drilling of the Snake River Plain" held its inaugural workshop in Twin Falls, Idaho, U.S.A. on 18-21 May 2006. This inter-disciplinary workshop, sponsored by the International Continental Scientific Drilling Program (ICDP), explored the major scientific and logistical issues central to a transect of boreholes along the hotspot track and addressing the geochemical evolution of continental lithosphere in response to interaction with deepseated mantle hotspots or plumes. A series of four to six bore holes is envisioned, each about 1.5-2.0 km deep and located along the axis of the Snake River Plain. The holes will specifically target the origin and evolution of hotspot-related volcanism in space and time. To accomplish scientific and logistical planning, sixty scientists from six countries attended the workshop.

During the first day, keynote speakers highlighted different aspects of the hotspot system, including heat flow, tectonics, basalt and rhyolite geochemistry, and paleoclimatic and cyclostratigraphic studies of paleolake sediments deposited in basins formed in the wake of the hotspot. Results of the Hawaii Scientific Drilling Project and the logistics of basalt drilling were described as well. The first day closed with presentations on drilling platforms, downhole logging tools, cyberinfrastructure, and the proposal process in the ICDP and Drilling, Observation and Sampling of the Earth's Continental Crust (DOSECC). The second day consisted of a field trip to potential drilling sites that contrasted stratigraphic differences between the basalt-dominated eastern Snake River Plain and the sediment-rich western plain that is overlain and underlain by hotspot basalts with distinct origins. On the third day, break-out sessions were conducted on the following topics, ending with ideas on how to target a drilling campaign addressing key questions in each of these areas: basalt geochemistry and isotope chemistry, rhyolite geochemistry and volcanology, hydrothermal systems and alteration, sedimentation-paleoclimate-cyclostratigraphy, and geophysics. The day concluded with a visit to the Snake River Canyon north of Twin Falls to examine a high-temperature rhyolite flow, overlain by fluvial and lacustrine sediments, and several hundred feet of basalt lava flows. The final day saw a wrap-up session that summarized findings of the preceding sessions and a layout of an action plan to move the project further towards realization. 
A key goal of the Snake River Plain Scientific Drilling Project is to constrain how mantle hotspots interact with the continental lithosphere and how this interaction is reflected in the geochemical evolution of the mantle-derived magmas. To achieve these goals, a transect is proposed over the paleocontinental margin across different zones of the lithosphere. During the first stage, lavas that erupted through Mesozoic accreted terranes of oceanic provenance should be drilled. Later drilling will sample lavas derived from magma that traveled through a progressively thicker and older lithosphere of Proterozoic to Archean age and will illuminate how changes in the thickness, age, and composition of the underlying mantle lithosphere affect basalt chemistry. This strategy will also allow the sampling of extensive sections of basalt at relatively low cost. In addition, the unique potential to resolve unanswered questions about the evolution of the Plio-Pleistocene paleoclimate by drilling paleo-Lake Idaho was discussed.

It was also suggested that one deep hole should attempt to penetrate the early high-temperature rhyolites underlying the basalts, to constrain both the volume of felsic eruptives and the crustal response to passage of the hotspot. Since most Snake River Plain rhyolites represent crustal melts formed in response to the intrusion of mafic magma into the lower and middle crust, the volume of rhyolite allows one to infer the volume of mafic magma trapped in the crust. The nature of pre-rhyolite volcanism and sedimentation reflects the crustal response to the passage of the hotspot. It was agreed that the best strategy to achieve this goal is to deepen one of the existing bore holes already penetrating rhyolite at depth at the Idaho National Laboratory (INL) site.

The western Snake River Plain graben contained a deep lake (Lake Idaho) for much of its late Pliocene to early Pleistocene history. Lake Idaho sediments include diatomrich rhythmites spanning the Pliocene-Pleistocene boundary and preserve a detailed record of climatic change during this critical transition. Scientific objectives include (1) the late Neogene history of North Pacific atmospheric water transport into the Great Basin of the western North American craton and possible linkages to the initiation of Northern Hemisphere glaciation, (2) the response of the Great Basin hydrological system to the Pliocene climatic optimum, and (3) the development of a master reference section for later examination of lacustrine sediments interbedded with basalt and rhyolite in the eastern Snake River Plain. Proponents of the Lake Idaho Drilling component will develop the rationale for this scientific effort independently, but complementary with the planned drilling of the volcanic rocks that underlie the lake sediments.

The HOTSPOT workshop benefited from bringing together scientists from a wide range of disciplines to address issues related to the central theme of hotspot volcanism. In particular, combining studies of hotspot dynamics and paleoclimate records within the sedimentary systems forming in response to hotspot passage provides a strong opportunity for interdisciplinary science. The geochemical studies will complement EarthScope investigations of crustal and lithospheric structure by providing mass-balance constraints on melt extraction from the mantle and partial melting of the crust. A significant educational and outreach component is planned as well.

The participants resolved to pursue this project by submitting pre-proposals to the ICDP and the U.S. National Science Foundation (NSF). This planning effort will require compiling a database of existing geological and geophysical data and full coordination with EarthScope geophysical investigations A HOTSPOT session at the American Geophysical Union meeting in San Francisco in December 2006 is in preparation.

\section{References}

Shervais, J.W., Vetter, S.K. and Hanan, B.B., 2006. A Layered Mafic Sill Complex beneath the Eastern Snake River Plain: Evidence from Cyclic Geochemical Variations in Basalt, Geology, 34: 365-368.

Smith, G.R., and Patterson, W.P., 1994. Mio-Pliocene seasonality on the Snake River plain: comparison of faunal and oxygen isotopic evidence. Palaeogeogr., Palaeoclim., Palaeoecol., 107 (3-4):291-302, doi:10.1016/0031-0182(94)90101-5.

\section{Authors}

John W. Shervais, Room 205A, Geology Department, Utah State University, 4505 Old Main Hill, Logan, Utah 843224505, U.S.A., e-mail: shervais@cc.usu.edu

Michael J. Branney, Department of Geology, University of Leicester, University Road, Leicester LE1 7RH, U.K.

Dennis J. Geist, Department of Geological Sciences, University of Idaho, Moscow, Idaho 83844-3022, U.S.A.

Barry B. Hanan, Department of Geological Sciences, MC1020, San Diego State University, 5500 Campanile Drive, San Diego, Calif. 92182-1020, U.S.A.

Scott Hughes, Department of Geosciences, Idaho State University, Campus Box 8072, 785 South $8^{\text {th }}$ Avenue, Pocatello, Idaho 83209-8072, U.S.A.

Alexander A. Prokopenko, Department of Geological Sciences, University of South Carolina, 701 Sumter Street, Columbia, S.C. 29208, U.S.A.

Douglas F. Williams, Department of Geological Sciences, University of South Carolina, 701 Sumter Street, Columbia, S.C. 29208 , U.S.A.

\section{Related Web Links}

http://snakeriver.icdp-online.org http://www.earthscope.org/ 